\title{
Introduction to the Special Issue of "Scientia et Fides" on Mariano Artigas
}

\section{SANTIAGO COLLADO}

Universidad de Navarra

scollado@unav.es

The occasion for the elaboration of this issue was the tenth anniversary of the death of Mariano Artigas, which took place on December 23, 2006. A period of ten years is a good excuse to do something allowed by the academic life though, paradoxically, not usually encouraged by its demands, namely, to take a moment to stop, to look back, and to think.

I had the opportunity to work alongside Artigas during the last six years of his earthly life. Those years left a mark in me of which I am starting, I believe, to be conscious. In the contributions made in this issue, many of those who participated-who represented only a portion of those who desired to contribute but have unfortunately not been able to do so for many different reasons - manifest the footprint that knowing Artigas or reading his works has left not only in their academic life, but also in their personal life.

It is difficult to estimate the influence that one person can exert in others. It is also difficult to thoroughly understand the real scope of a legacy left by personalities like Artigas, even though we have statements and works that make it known. I think that what can be seen in these testimonies is only the tip of an enormous iceberg that is prolonged in space and, primarily, in 
time. In the contributions gathered in this issue, one can sense the extension and the depth that Artigas' influence has on those of us who knew him and will have on those who, like him, are academically committed to truth. Some of these articles, such as that of María Ángeles Victoria, do explicitly display some of the dimensions of the mentioned influence.

One of the initiatives brought about by Artigas that has continued to grow over the past ten years is the "Ciencia, Razón y Fe" (Science, Reason, and Faith) group, normally abbreviated to "CRYF." José Manuel Giménez Amaya, who acted as its director for six years, made a more serene reflection on CRYF and the services it has been called to render in the university. I myself had the privilege to witness its outset. When CRYF was established in 2002, one of the small but important decisions that had to be taken concerned the name of the group. Giving a name was never considered-though some might nowadays do-as a trivial activity; in some cultures, name aims at expressing the essence of the reality being denominated. This was our desire when we joined the terms for which the abbreviation "CRYF" stands.

The first book published by Artigas, not directly related to the findings of his three doctoral theses, was titled Ciencia, razón y fe (1984). Artigas exhibited, at first, certain opposition to the proposal of naming the group "Ciencia, Razón y Fe" precisely because it was the very title of his first book; he did not want to stand out in this small detail. As a matter of fact, the reason because of which Artigas chose that title for his book-namely, the necessity of distinguishing without separating those three methodical fields-was the very reason that made it the most adequate name to denominate the group. Science ${ }^{1}$ is obviously a rational activity, but it does not exhaust the entire rationality of which human being is capable: reason, understood as man's capacity of knowing the truth, surpasses science. Reason and therefore science should not-or perhaps cannot-separate themselves from faith:

When I mention 'science' in singular, I am referring to the empirical science, which is the way we ordinarily understand 'science' in our everyday conversation. Perhaps, talking of 'sciences' in plural would be more proper; Artigas, however, alludes to the empirical science both in plural and in singular. I think his philosophy of science indirectly offers a basis for the possibility of talking about it also in singular. 
"Faith and reason are like two wings on which the human spirit rises to the contemplation of truth," as Saint John Paul II writes in the Encyclical Fides et ratio (1998).

Not separating science from faith does not entail mixing them or joining them illegitimately. One of the greatest challenges of human thinking is to distinguish without separating or to join without equaling different realities which have something in common but are not identical. It could be that Parmenides was one of the first thinkers who radically evinced the difficulty of the above mentioned challenge.

Reason seeks economy but often times, in order to understand reality, one has to wear oneself out. This is actually what Artigas did: he wore himself out in order to grasp how science can offer authentic truths and bring us to the comprehension of non-scientific realities. Artigas, in fact, received a scientific formation that was initially inserted in the realm of physics but extends to biology².

One could perceive in Artigas' writings a step-by-step evolution from a vision of science that lightly emphasized its limitation ${ }^{3}$ to a vision of science that expressed more and more clearly his own conviction since the beginning: science is a path that leads toward authentic truths, although these do not represent the truth in its entirety. This, I think, is a key point in his philosophy. Harmonizing science, reason, and faith and explaining their mutual relation entails pointing out the nature of the truths provided by science or sciences rather than declaring science's presumed limitations. The attempt to keep together the realities signified by those names and, at the same time, to ward off superficial quarrels or profound enmities among them penetrates not only his academic but also personal itinerary.

In my opinion, the core of Artigas' works was constituted by an authentic philosophy of science, namely, philosophy in the traditional sense of the

2 In his contribution, Javier Novo reaches some conclusions based on this differentiation in Artigas' scientific formation. It is evident that physical rationality was the one that influenced his philosophy of science the most.

3 Las fronteras del evolucionismo was published a year after the publication of the first edition of Ciencia, razón y fe. 
word, but put into dialogue with authors and problems of his time. There is nowadays, especially in the Anglo-Saxon environment, a renewed interest in philosophy of science, carried out with a perspective inspired by analytical approaches. The article written by Sebastián de Haro displays the problems that arise when the philosophy of science conducted by Artigas is compared to the philosophy of science currently done within the analytical tradition. Artigas endeavors to understand the truth provided by science starting from the empirical results yielded by different sciences but, at the same time, keenly avoids the temptation of conducting a "metascience" reduced to a science-of-science and strives to maintain philosophy's openness to dimensions of reality that escape the control of scientific rationality.

I am of the view that being a realist in philosophy entails maintaining that openness. One can easily perceive the fact that Professor Artigas, like other important philosophers of science with whom he was acquaintedKarl Popper being one of them-, focuses his attention on dimensions that transcend the very science. It is not a coincidence that Artigas was aware that ethics is, as Alfredo Marcos explains well in his contribution, the key to comprehend Popper's philosophy. Rubén Herce also highlights the ethical dimension as a significant part of the scientific endeavor in Artigas' thought. A philosophically realist approach to science requires, beyond question, the effort to go beyond it even from the methodical vantage point. I believe that this task's difficulty underlies many other difficulties faced by philosophers who belong to the analytical tradition.

His priesthood induced Artigas to strengthen his commitment to serve others. He sought in a particular way to serve those who shared his faith. This accounts for the orientation of his investigations toward issues-considered as controversial now and then-concerning the relation between faith and reason, which could arouse certain dread in investigators who attempted to approach them. The exhaustive research into Galileo's case, which resulted in a great trilogy about this episode, is an example of his disposition toward serving others, which is manifested in his being at truth's service. The article of José María Valderas traces the formation process of Artigas' interest in the subject-matters in which he was a pioneer in the Spanish speaking world. 
He did not endeavor to achieve academic success, although he clearly understood that academic excellence was necessary to widen the extension and the depth of the service that enlivened his work. That is why he cultivated and got to have a good command of popular writing while striving at the same time to understand the epistemological bases that underlie the problems being dealt with. Among his works, there are many "easy-to-read" writings aimed at persons without any specific academic formation. In spite of this, he actively worked toward getting his articles published-something which he managed to do-by the most prestigious publishing companies in the academic world. He perceived very early the importance of being present in the digital world and encouraged the members of the then newly found CRYF to create and manage a lively webpage in which the works that were out of copyright could be readily made accessible.

He did not consider the authors he studied as enemies to overcome. He studied their thinking slowly and carefully; he was always respectful in his dialogue toward others, though he could display critical or sometimes very critical attitudes toward certain ideas when it comes to defending the truth. The book Oráculos de la Ciencia on which Jaume Navarro's article centers is an example of this attitude. This very disposition led him to consider some authors differently from how the common stereotypes portray them. In point of fact, the writings of Alfredo Marcos, Francisco Javier López Ruiz, and Geoffrey Woollard make this aspect manifest.

In Artigas' legacy, one can definitely recognize a characteristic that can also be found in other thinkers with solid faith and convictions, such as George Lemaitre, who is discussed in Eduardo Riaza's and Pablo de Felipe's articles. Artigas' faith was not by any means an obstacle for him to put reason into practice to the full. His faith was precisely that which nurtured his passion for truth and provided him the convictions that reality contains treasures that reason ought to discover. This perspective goes beyond a mere exhibition of a respectful harmony or a simple compatibility between faith and reason; it shows, rather, a man with an authentic faith who seeks to understand reality by overcoming the difficulties involved in this task (fides quaerens intellectum) and manifests that reason is, in all its aspects and levels, 
faith's great ally (intellego ut credam). This outlook helps one to recognize, furthermore, the far-reaching reality conveyed in the comparison made by Fides et ratio between faith and reason on the one hand and the spirit who seeks the truth with its two wings on the other.

The content of the twenty six articles in this issue is highly diverse, though all of them express gratitude and admiration toward Artigas. Some authors convey how Artigas has contributed to their own intellectual and even vital itinerary. Others examine issues dealt with directly by Artigas or problems directly or indirectly connected with those investigated by him. They relate their personal memories of Artigas, as well as their intellectual concerns or subjects of investigation. In this short introduction, I have not been able to refer to all authors who figure in this issue; since everyone has rendered priceless contribution, mentioning all of them would imply taking up more space than what is deemed reasonable.

The contributions have been arranged according to each subject's relation to Artigas. This issue has been divided into four sections, although the common elements in some of them could have justified another way of organizing the articles. The first section covers, in a very wide sense, Artigas' life and thinking from the historical vantage point; we could say that, in this section, Artigas is being situated within time. The second section gathers the contributions that reflect on some of the proposals made by Artigas. The third section contains the articles that put Artigas' thinking in relationship with that of other authors. Finally, the fourth section includes articles that have to do with diverse subjects that either concern indirectly Artigas' works and interests or were considered from standpoints different from his. Moreover, an appendix carefully prepared by José Ángel García Cuadrado, based on the curriculum that Artigas himself elaborated-though more material was added to it after his passing-, is added. Hence, seeing that the content of the appendix has been drawn mostly from the mentioned curriculum, it can be said that Artigas himself is the author of the appendix. I think fit to consider this appendix as Artigas' posthumous and unpublished contribution which he obviously would not have submitted to any journal. 
I finally wish to express my gratefulness to all those who have made the publication of this special issue possible: to the Faculty of Theology of Nicolaus Copernicus University in Torun and to its academic authorities who facilitate the journal Scientia et Fides; to the University of Navarra which has proved to be a habitat without which CRYF would not be viable; to the editors of the journal Scientia et Fides who, under the leadership of Piotr Roszak and Javier Sánchez Cañizares, have put to use all the resources of this journal-especially the human ones-for the sake of this issue's completion. They have been able to recognize the significance of this project since the very outset, when the then director of CRYF Giménez Amaya voiced the idea. I also manifest my thankfulness to those who, with their articles, played a part in making Artigas' legacy known from diverse points of view. I thank, furthermore, the effort of the members of CRYF who maintain Artigas' university spirit alive and passed it on to those of us who started the group. Likewise, I cannot fail to appreciate the invaluable work of meticulous reading, proofreading, and correction carried out by Gloria Balderas, without which this project would not have been concluded on time. Needless to say, I finally direct my gratefulness in a special way and for so many motives to Mariano Artigas; as I already said in the beginning, what is being disclosed in this issue is only the tip of an iceberg. May our own limitations not impede the progress of this iceberg, which I hope will yield more and more fruits. 